International Journal of Agriculture, Environment and Bioresearch

Vol. 06, No. 01; 2021

ISSN: $2456-8643$

\title{
INCIDENCE OF FETUSES WASTAGE FROM SLAUGHTERING OF PREGNANT COWS AND ITS ECONOMIC IMPLICATION AT JALINGO ABATTOIR, TARABA STATE, NIGERIA
}

\author{
Usman D.D ${ }^{1}$, Abdullahi S.B ${ }^{2}$, Zungum I.U ${ }^{3}$, Fauziya K.M ${ }^{1}$, Hammanjoda S.A ${ }^{1}$, Adamu J.L ${ }^{4}$ Magama Y.A ${ }^{5}$ and \\ Babanlungu Z.A ${ }^{6}$ \\ ${ }^{1}$ Department of Biological Sciences, Taraba State University, Jalingo, Taraba State, Nigeria. \\ ${ }^{2}$ Department of Crop Production, College of Education, Jalingo, Taraba State, Nigeria \\ ${ }^{3}$ Department of Biological Sciences, Federal University, Gashua, Yobe State, Nigeria. \\ ${ }^{4}$ Department of Animal health and production technology, federal polytechnic Bali, Taraba state \\ ${ }^{5}$ Department of Biological Sciences, College of Education, Gumel, Jigawa State, Nigeria. \\ ${ }^{6}$ Department of Environmental Management, Federal University of Technology, Owerri, Imo State.
}

https://doi.org/10.35410/IJAEB.2021.5609

\begin{abstract}
This study was conducted to assess the prevalence of fetuses wastage and its economic implication from slaughtering pregnant cows at jalingo abattoir, jalingo, Taraba State, Nigeria, to fill the research gap in relationship with this thematic. The study was carried out between September and October, 2018. The total of Cows slaughtered during the study period at Jalingo abattoirwas 3,985, out of a total of 3,975 cattle slaughtered during the study period 2,142 $(53.91 \%)$ were female and $1,832(46.00 \%)$ were male. The study revealed an incidence rate of $7.55 \%$ over the period of study. The throughout the study period, 162 fetuses were recovered during the study period. Financial losses accrued from the fetuses wasted were within the range of 11.4 million to 16.2 million naira only. The study advocates that the practice of fetal wastage due to the slaughter of pregnant cows should be discouraged so that the demand for beef is met. The results also attested that slaughtering pregnant Cows constitute a strong constraint on cattle industry development in Nigeria. Urgent measures should be put in place, such as adequate laws enforcement on routine veterinary examinations at slaughter center as well as livestock owner's sensitization are needed to reduce selling of pregnant cowsduring calving.
\end{abstract}

Keywords: Fetal Wastage, Cows, Pregnant, Slaughtered, Abattoir, Jalingo, Nigeria.

\section{INTRODUCTION}

Animal protein consumption is very important in body defense mechanisms due to its better balance of amino acids (Gillespie, J.R.et al., 2003). These proteins are mainly provided by cattle for human population (Akpabio, U. and Babalola, A. 2014). In Africa, cattle are of crucial importance through their contribution to the improvement of nutritional status and the eco-nomic growth of their owners (Akpabio, U. and Babalola, A.S. 2014). As reported in many African countries, cattle are mainly reared for meat and milk production. They also provide job opportunities and represent an important source of income and energy, as well as skin, hair, hide products, and manure as by-product (Adama, J.Y., Shiawoya, E.L. and Michael, N. 2011). 
Vol. 06, No. 01; 2021

ISSN: $2456-8643$

However, in Africa, the annual consumption of animal protein remains very low compared to what is reported in Australia and the USA (approximately $115.5 \mathrm{~kg} /$ person/year) and even low compared to the global average of $41.9 \mathrm{~kg} /$ person(Food and Agriculture Organization.et al., 2013).

In the Nigeria, more specifically, livestock contributes up to $9.2 \%$ of the gross domestic product and plays a crucial role in the livelihood of the local population. Cattle, which is the most reared livestock and the most con-sumed in the country, contributes to more than $50 \%$ of the total meat consumption (Okorie-Kanu, O.J., Ezenduka, E.V., Okorie-kanu, C.O., Anyaoha, C.O., Attah, C.A., Ejiofor, T.E. and Onwumere- Idolor, S.O. 2018).

Nigeria cattle herd size is about $1,005,385$ heads representing $11 \%$ of overall livestock popu-lation (Ejiofor, T.E. and Onwumere- Idolor, S.O.2018), while the pastoral potential is estimated between 30 and 40 million heads showing how much protein availability is a serious challenge (Bisimwa, N.P., Lugano, R.M., Bwihangane, B.A., Wasso, S.D., Kinimi, E., Banswe, G. and Bajope, 2018).

This low cattle productivity observed in Nigeria as in other African countries is constrained by several factors such as disease, inadequate nutrition, poor management, and low biosecurity practices, with little or no veterinary attention, low genetic potential of native livestock, lack of concrete national policies, low quality feeds and higher costs of commercial feed, insecurity in rural regions, and reproductive wast-ages (Mshelia, D., Maina, V.A. and Aminu, M.D.2015). All these factors have constrained live-stock production to remain at a subsistence level (OkorieKanu, O.J., Ezenduka, E.V., Okorie-kanu, C.O., Anyaoha, C.O., Attah, C.A., Ejiofor, T.E. and Onwumere- Idolor, S.O., 2018).In addition, due to the steady animal protein demand accentuated by population growth, illiteracy, poverty of farmers, and disease condition of animals, farmers sell off animals without considering their fer-tility stage, especially breeding stock and pregnant animals followed by inadequate meat inspection prac-tices (Garba, S. and Hassan, A.A. 2002). Thus, fetuses are usually discovered during postmortem meat inspection that may have negative effect on livestock growth capacity, giv-ing poor meat quality to consumers, and represent a serious problem for animal ethics (Atawalna, J., Emikpe, B.O., Shaibu, E., Mensah, A., Eyarefe, O.D. and Folitse, R.D, 2013). This leads toward not only wastage of scarce protein by supply-ing poor quality meat products to consumers, but also a decrease in livestock growth capacity at country level as well as low herd replacement rates (Ezenduka, E.V., Okorie-kanu, C.O., Anyaoha, C.O., Attah, C.A., Ejiofor, T.E. and Onwumere- Idolor, S.O, 2018).

Wastage of fetuses through the indiscrimi-nate slaughter of pregnant female animals is one of the most destructive practices humankind has ever used against his production endeavor. Lack of leg-islation strictly regulating abattoir construction and operations, the unavailability of modern abattoir where proper antemortem examinations of slaugh-tered animals are practiced to eliminate slaughtering of pregnant cows remains the factor of this practice spreading (Alhaji, N.B.et al., 2011).

In Africa, calf losses associated with the slaughter of pregnant cows are enormous and have been documented in several countries such as Nigeria (Ademola, A.I.et al., 2008], Cameroon [ Ndi, C., Tambi, N.E. and Agharih, N.W.1993). Tanzania [Swai, E.S., Ayubu, H. and Mhina, B.SC 2014) and Ghana (Atawalna, J., Emikpe, B.O., Shaibu, E., Mensah, A., Eyarefe, O.D. and Folitse, R.D., 2013) 
Vol. 06, No. 01; 2021

ISSN: $2456-8643$

Despite the concern raised on this thematic in other countries and Nigeria, no study has been carried out in Taraba state particularly in Jalingo abattoir to investigate the empirical evidence of the fetal wastages incidence through slaughter of pregnant cattle and their effect on public health, livestock production, national herd size, and economic implication to better planning, and implement policies on meat inspection.

The slaughtering of pregnant cows/heifers has double negative effect of an economic impact on the national GDP and a long term consequence on protein supply because these wasted fetuses that have lost their chances of survival and reproducing their own kind.

With the increasing human population in Nigeria, there is a very high demand for animal protein to meet the world health organization(WHO) recommended $56 \mathrm{~g}$ protein intake for a $75 \mathrm{~kg}$ man and $48 \mathrm{~g}$ for $56 \mathrm{~kg}$ woman, (www.afpafitness.com 1985). However, due to this high numbers of fetal wastage, the World Health Organization target is far from being achieved. This study is justified because if the current trend of slaughtering pregnant animals in Nigerian abattoirs and elsewhere is not arrested, this will eventually lead to a decrease in our national cattle population and hence low protein intake and low economic returns for cattle farmers, low disposable income which will negatively affect the national GDP.

According to Mukasaet al. (2006), herd productivity can be affected by a range of disease problems and reproductive wastages. Livestock are very important assets in Africa and contributes to the nutritional status and the economic growth of their owners. They are reared for several reasons but mostly for animal protein supply. The steady growth in demand for meat accompanied by increase in the price has led to the practice of slaughtering breeding and pregnant animals in most Nigerian abattoirs (Craig, 1982 \&Taiwo et al., 2006). Most livestock farmers also sell off their animals without confirming the fertility stage before selling them off due to poverty, illiteracy and disease condition of the animals (Toulmin, 1986). Animals commonly slaughtered for meat in Nigeria are cattle, goat, sheep, pig, camel, donkeys, horses and other edible game/forest animals (Alabi, 2003). The foetuses are usually discovered during post mortem meat inspection at the abattoirs. Foetal wastage has been reported in other abattoirs in Nigeria. A rate of 2.6\% slaughter of pregnant animals was reported in Enugu (Wosu, 1988). At Doma abattoir Nasarawa state a $0.32 \%$ slaughter of pregnant cow was reported (Idahor et al, 2009). Therefore, this study was carried out to determine the incidence of fetal wastage from slaughtering pregnant cows at the Jalingo Abattoir, Taraba State.

\section{MATERIALS AND METHOD}

Description of the Study Area: This was carried out between September and October, 2018 at the Jalingo abattoir. The Jalingo abattoir is located at Sabon Gari in north eastern part of Nigeria on latitude $8.89 \mathrm{~N}$ and longitude11.36E and its situated at elevation 349 meters above sea level, and is the largest abattoir in Taraba State and also has the largest number of animals being slaughtered in Jalingo. The abattoir receives cattle mainly from Jalingo and the neighboring villages, and provides most of the meat consume in cosmopolitan city of Jalingo. 


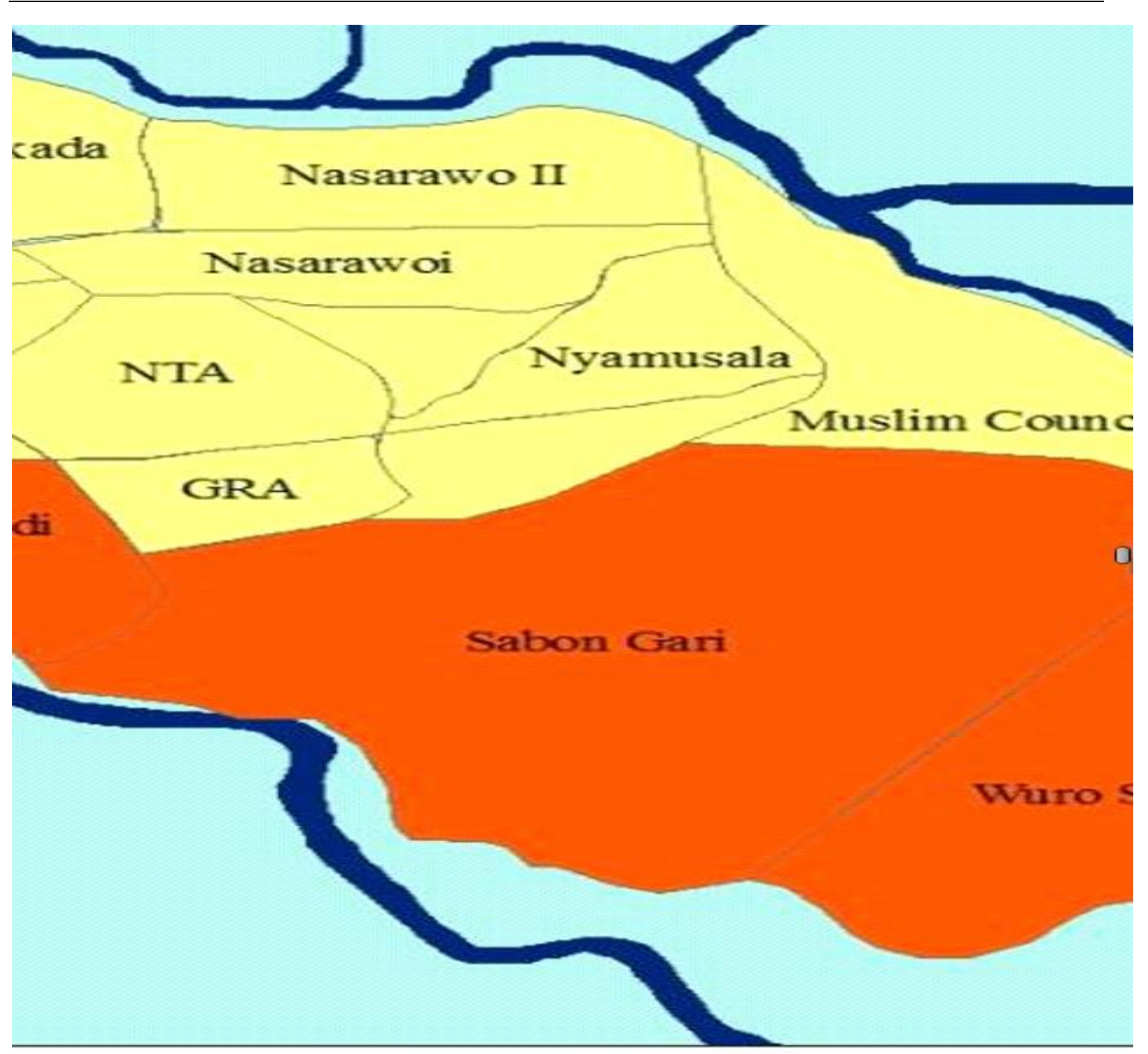

\section{Data Collection}

From September to October 2018, data on the total number of male and female Cows slaughtered and number of the fetuses' wastage was collected on a daily basis except (Saturday and Sunday) between $6 \mathrm{am}$ to $10 \mathrm{am}$. Total number of male, non-pregnant female cattle, pregnant cows slaughtered and the ages of the fetuses were collected on a daily basis. The results were analyzed to determine the prevalence of pregnancy in the slaughtered cows, the percentage of avoidable calf wastage and the ratio of cows to bulls slaughtered. The pregnancy status of the cows was first determined by visual assessment and palpation of the exposed uterus after slaughter and then confirmed by dissecting the uteri of the slaughtered cows. The method of collection involved visiting the abattoir as early as 5:00 am every morning and counting the total number of 
cattle and number of male and female before slaughter. An introductory letter was obtained from the department and presented at every necessary place of data collection.

\section{Determination the economic implications of fetuses wastages}

The economic wastage of foetuses was determined by multiplying the total number of foetal wastage in cattle by the amount worth in naira it would have been sold for if their gestation was not terminated

Example in jalingo abbatoir some full grown cattle is sold at \#70,000 to \#100,000, therefore, the amount lost was calculated as:

6(total number of foetuses wasted) \#7000 to \#100,000

$$
\# 420,000 \text { to } \# 600,000
$$

This means that an amount of \#420,000 to \#600,000 is lost

\section{Data Analysis}

Data for this study was entered, stored and analyzed using Microsoft excel statistical software. Descriptive statistics such as simple averages and percentages. The prevalence of fetal wastage was determined by dividing the number of wasted fetuses by the number of slaughtered females and also expressed the risk of fetal wastageassociated with slaughtering any pregnant females. The prevalence of pregnant cows slaughtered was determined as the proportion of the total number of slaughtered females that was pregnant at the time of slaughter.

\section{RESULTS AND DISCUSSION}

During the study period the total of 3,975 cows were slaughtered in jalingo abattoir over a period of 2 months with 1,834 males i.e. (46.14\%) and 2,145 females (53.93\%). Examination of the reproductive organs from the female's cows revealed that 162 i.e. $7.5 \%$ of them are pregnant in various trimester.

Table 1: shows the breakdown of the slaughtered females cattles, foetal wastages and the incidence of the foetal wastages.

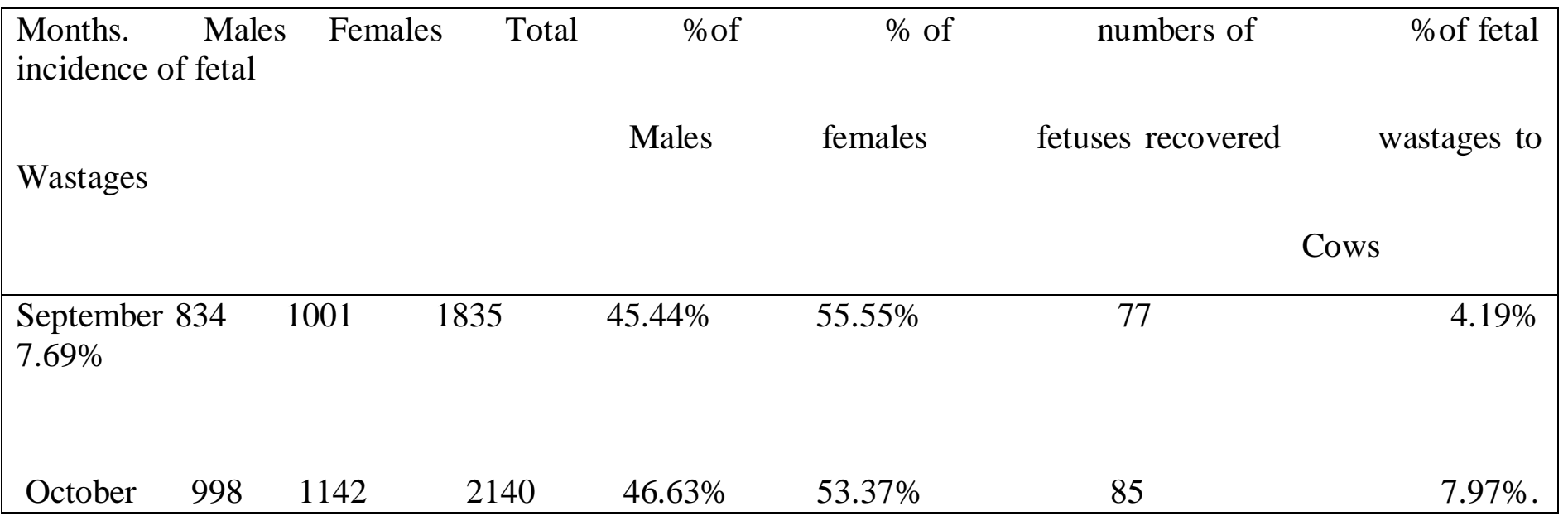




\section{International Journal of Agriculture, Environment and Bioresearch}

Vol. 06, No. 01; 2021

ISSN: $2456-8643$

$7.44 \%$

Total

$1832 \quad 2143$

3975

$46.08 \%$

$53.91 \%$

162.

$4.07 \%$

$7.55 \%$

\section{Incidence of futuses wastage at jalingo abattoir}

The slaughter record of cows slaughtered at Jalingo abattoir between September and October 2018 were shown table 1 above. The total number of cows slaughtered during the study period was 3,975. The number cows slaughtered peaked in the month of October, and number of fetuses wasted was also highest in the month of October. One fetus was wasted for every nine cows slaughtered or for every seven cows slaughtered.In the first month (September), a total of 1835 cows were slaughtered out of which 1001 (55.55\%) were females, a total of 77 wasted fetuses were recorded this shows that 77 out 1001 female cows are pregnant, hence the incidence of fetuses wastage (percentages of fetuses to the pregnant cows) in the first month (September)is $7.69 \%$

In the second month (October), a total of 1832cows were slaughtered out of which $1142(53.37 \%)$ were females, a total of 85 wasted fetuses were recorded. This shows that 85 out 1832 female cows are pregnant, hence the incidence of fetuses wastage (percentages of fetuses to the pregnant cows) in the second month of October is $(7.44 \%)$. Generally during the study period, a total 2140 slaughtered cows are females with over 162 wasted fetuses which gives the total of $7.55 \%$ fetuses incidence of wastage.

Table 2: shows the distribution of fetuses recovered from the slaughter of pregnant cows

\begin{tabular}{lcccc}
\hline MONTHS & $1-3$ months & $4-6$ months & $7-9$ months & Total \\
\hline $\begin{array}{l}\text { SEPTEMBER } \\
77\end{array}$ & 28 & 30 & 19 \\
$(36.4 \%)$ & $(38.9 \%)$ & $(24.7 \%)$ & & \\
OCTOBER & 31 & & 21 & 28 \\
85 & $(24.7 \%)$ & $(32.9 \%)$ & & \\
$(36.5 \%)$ & 59 & $51 \quad(36.4 \%)(31.5 \%)$ & $(29.0 \%)$ &
\end{tabular}

Proportion of fetuses recovered from cows slaughtered in a month

The finding of this study revealed the age of fetuses recovered between September and October 2019. One hundred and sixty-two fetuses were recovered out of which ninety-seven $(60.5 \%)$ 
were recovered in the second and third trimesters. The total number of wasted fetuses recovered in the trimester of pregnancy was high in the month of October.

In the first month,77 wasted fetuses were recovered, their ages were calculated using crown anus, 30 fetuses are at the ages of 1-3 months, they are recorded under first trimester. 19 fetuses of 4-6 ages are the second trimester fetuses , 6-9 are the third trimester fetuses which are 28 in numbersIn the second month (October) 85 wasted fetuses were recovered, their ages were also calculated using crown anus, 21 fetuses are at the ages of 1-3 months, they are also recorded under first trimester. 28 fetuses of 4-6 ages are the second trimester fetuses , 6-9 are the third trimester fetuses which are 31 in numbers.
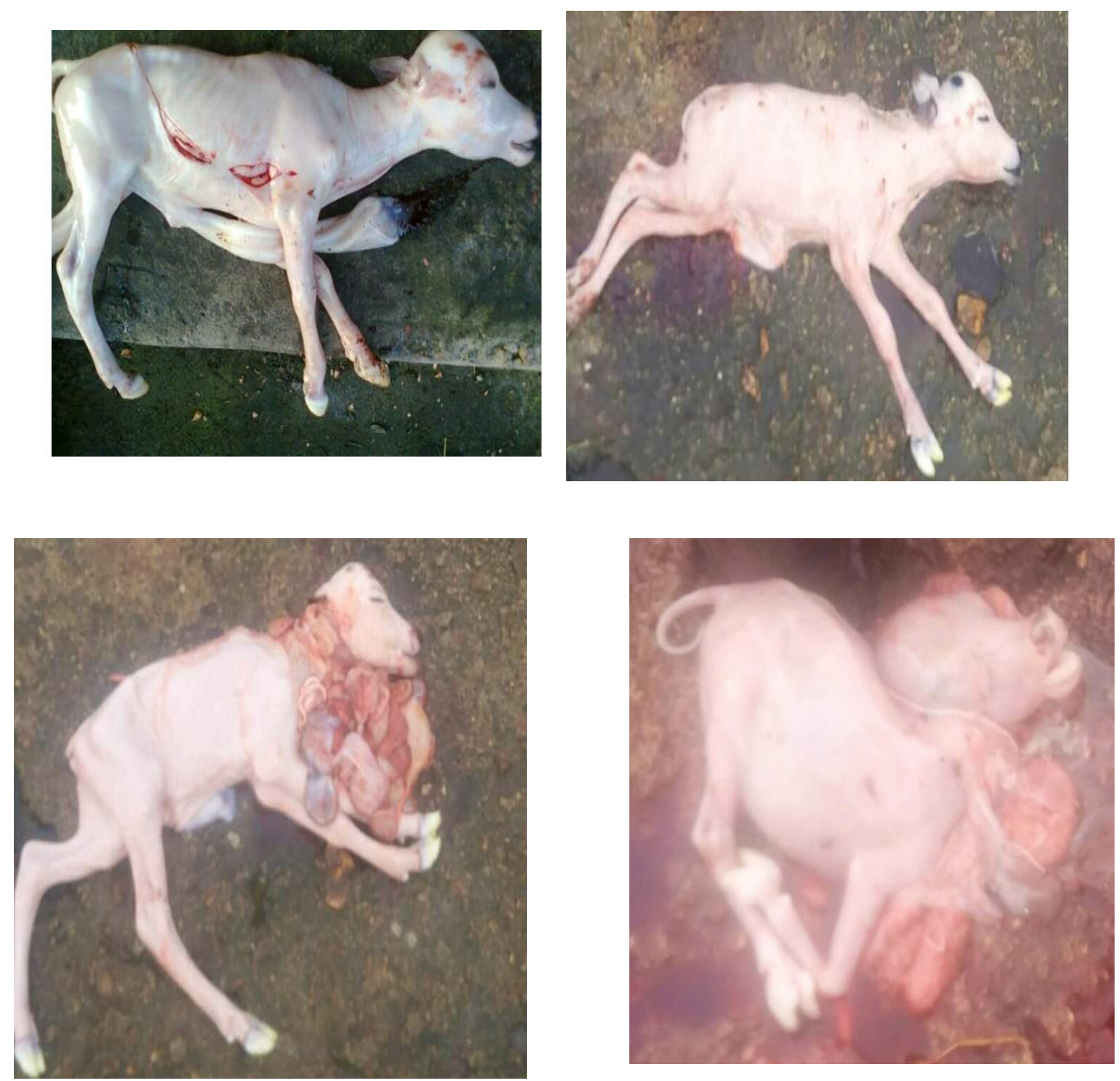
Table 3: Shows the sex ratio of fetuses' wastage from the slaughtered of pregnant cows $\begin{array}{llll}\text { MONTHS } & 1-3 \text { months } & 4-6 \text { months } & 7-9 \text { months }\end{array}$ SEPTEMBER 28 30 19 77 OCTOBER 31 21 28 85

$$
59
$$
51 $47 \quad 162$

TOTAL

\section{Some pictures of fetuses captured during the study}

When the sample were collected at the point of slaughter, and analyzed immediately for sex and age. Sex was determined by physically examining the external genitalia. The Sex ratios of the fetuses wasted were calculated and numbers of fetuses and their distribution within the study period are shown in the table above. The finding revealed that 36.4\% of the slaughtered cows $(59$ cows) were in their $1^{\text {st }}$ trimester ( $0-3$ months), $31.5 \%$ (51 cows) were in their $2^{\text {nd }}$ trimester (4-6 months), and only $29.0 \%$ (47 cows) were in their $3^{\text {rd }}$ trimester (7-9 months)

\begin{tabular}{cccc}
\hline MONTHS & $\begin{array}{c}\text { Numbers Female } \\
\text { Fetuses Wastage }\end{array}$ & Numbers Male & Fetuses Wastage
\end{tabular}$\quad$ Total Ratio of Females to Males

\begin{tabular}{lcccc}
\hline SEPTEMBER & $31(40.26 \%)$ & $46(59.74 \%)$ & 77 & $3: 2$ \\
OCTOBER & $33(38.82 \%)$ & $52(61.17 \%)$ & 85 & $3: 2$ \\
\hline Total & $64(39.50 \%)$ & $98(60.49 \%)$ & 162 & $3: 2$ \\
\hline
\end{tabular}

A total of 77 fetuses were wasted during the month of September in Jalingo abattoir which comprises of 31 males and 46 females which gives the ratio female to male $3: 2$,

In the second month (October), a total 85 fetuses were wasted, 33 males and 52 females, which also gives the ratio of females to males $3: 2$

In general, during the study period, a total of 162 fetuses were wasted within the month of September to October in Jalingo abattoir of which 64 are males and 98 are females, these gives the ratio of females to males as 3:2

Table 4: Shows the economic implications of fetuses' wastages in Nigeria currency(naira)

\begin{tabular}{lllll}
\hline $\begin{array}{l}\text { MONTHS } \\
\text { F(S2) }\end{array}$ & NF & S1 & S2 & F(S1)
\end{tabular}

\begin{tabular}{llllll}
\hline September & 77 & $\# 70,000$ & $\# 100,000$ & $\# 5,390,000$ & $\# 7,700,000$ \\
October & 85 & $\# 70,000$ & $\# 100,000$ & $\# 5,950,000$ & $\# 8,500,000$
\end{tabular}


Vol. 06, No. 01; 2021

ISSN: $2456-8643$

TOTAL

162

$\# 11,340,000$

$\# 16,200,000$

The economic implications of fetuses wastage in jalingo abattoir within the 2 months of the study period were calculated monthly

Keys

NF: Numbers of fetuses wasted

S1: less sale amount of grown cow in Jalingo abattoir, which is \#70,0000

S2: High sale amount of grown cow in Jalingo abattoir, which is \#100,000

$\mathrm{NF}(\mathrm{S} 1)$ : The product of NF and S1, the less implication of fetuses wastage in naira

$\mathrm{NF}(\mathrm{S} 2)$ : The product of NF and S2, the high implication of fetuses wastage in naira.

77 fetuses were wasted in September during the study period, since a grown cattle were sold at N70,000 to N100,000, then the implications of fetuses wastage in September is equals to 77 multiply by \#70,000 to \#100,000 which gives \#5,390,000 to \#7,700,000. In October 85 fetuses were wasted, the implications of fetuses wastage in October is equals to 85 multiply by \#70,000 to N100,000 which gives \#5,950,000 to \#8,500,000.

Generally the summing of October and November wastages gives us the total economic implications of wastages at \#11,340,000 to \#16,200,000.

\section{DISCUSSION}

This finding revealed that the incidence rate of pregnant cows slaughtered in Jalingo abattoir was $7.55 \%$, were the finding of this study agrees with the finding of Salami et al., (2012), who reported that the incidence rate of slaughtered pregnant cows/heifers have shown that in Zaria abattoir the rate was $6.7 \%$, but disagrees with the research conducted in Enugu abattoir where the rate was 2.6\% (Wosu, 1988), in Doma abattoir the rate was 0.32\% (Idaho et al., 1989), in OkeOba abattoir Agege Lagos the rate was 1.8\% (1.50-2.10\%) over a period of 4 years study period (Ibironke, 2010) and in Lafenwa abattoir Abeokuta the rate was 10.7\% (Oduguwa et al., 2013). The differences in the incidence rates of slaughtered cattle between the current study and the previous reports cited above may be due to the differences in demand for beef meat in different Nigerian cities/towns. If the demand for beef is high, there will be a likelihood of a "shift to the left" where more female animals are channeled into the meat chain to augment the beef that comes mainly from the bulls. Another possible reason is the differences in sample size and duration of each study period e.g. some of these previous studies were carried out over a period of 4 years while the current study was carried out over a period of just over 2 months (72 days). Other most probable reasons of these variations in percentages of slaughtered pregnant cows could be due to season of study e.g. more animals are sold for slaughter during the dry season than during the rainy season in Nigeria. This is because livestock farmers are faced with limited quality and quantity of fodder during the dry season and are forced to offload some of their animals so as to be able to manage the rest through the dry season. Apart from the above reasons, there could be other unknown factors that could control these differences across cities and towns in Nigeria. When more sample sizes are studied over a long period of time (years), the pregnancy rates of slaughtered pregnant cows may become much clearer than what we have currently. The incidence rates of slaughtered other species of pregnant animals was higher than those reported 
Vol. 06, No. 01; 2021

ISSN: $2456-8643$

in cattle. For example, the incidence rates in slaughtered pregnant camels at the Sokoto abattoir was $50.4 \%$ (Bello et al., 2010) in slaughtered pregnant cows at Lafia abattoir was $29.5 \%$ (Idaho et al., 2013).

The finding also revealed the age of fetuses recovered between September and October 2019. One hundred and sixty-two fetuses were recovered out of which ninety-seven $(60.5 \%)$ were recovered in the second and third trimesters. The total number of wasted fetuses recovered in the trimester of pregnancy was highest in the month of October. The findings further confirm that of Oduguwa, B.O. et al., (2013), who reported that the record of cows slaughtered at Lafenwa abattoir between September and December 2008, where the total number of cows slaughtered during the study period was 15,112 , and the number of cows slaughtered peaked in the month of October as it is in this finding. Base on this findings, the highest number of pregnant cows was slaughtered in the month of October, which is also agrees with the findings of Oduguwa, B.O et al., (2013), who revealed that the highest number of pregnant cows was slaughtered in the month of October. $10.7 \%$ of all the cows slaughtered were pregnant. Similarly, the work of Adeyemi, A.B et al., (2016), who reported that the total number of animals slaughtered were 1,740 (from november2011- January 2012).

The Sex ratios of the fetuses wasted were calculated and numbers of fetuses and their distribution within the study period are shown in the table above. The finding revealed that $36.4 \%$ of the slaughtered cows (59 cows) were in their $1^{\text {st }}$ trimester (0-3 months), $31.5 \%$ (51 cows) were in their $2^{\text {nd }}$ trimester (4-6 months), and only $29.0 \%$ (47 cows) were in their $3^{\text {rd }}$ trimester (7-9 months). The findings of this study is in line with that of Valence, B.M, et al., (2019), who reported that most of the pregnant cows slaughtered are at the $1^{\text {st }}$ pregnancy trimester (58\%). This is not surprising, as in the first trimester it is very difficult to notice the gestation than at the second and third trimester. The findings in this study also revealed that one fetus was wasted for every (7) cows slaughtered. The ratio is higher than the findings of Muhammad et al (2008) which has (1:3) at Gombe abattoir, Sanusi et al (2006) has 1:15 at Jos abattoir, Fayemi et al., (2008) has 1:14 at four abattoirs in Ogun State, and Nwakpu et al., (2007) has 1:11 in Ebonyi State. As stated earlier, poor enforcement of existing legislation may account for the degree of fetal wastage in this study.

In the first month 77 wasted fetuses were recovered, their ages were calculated using crown anus, 30 fetuses are at the ages of 1-3 months, they are recorded under first trimester. 19 fetuses of 4-6 ages are the second trimester fetuses ,6-9 are the third trimester fetuses which are 28 in numbers.

In the second month (October) 85 wasted fetuses were recovered, their ages were also calculated using crown anus, 21 fetuses are at the ages of 1-3 months, they are also recorded under first trimester. 28 fetuses of 4-6 ages are the second trimester fetuses , 6-9 are the third trimester fetuses which are 31 in numbers

The findings of this study further revealed that, 77 fetuses were wasted in September during the study period, since a grown cattle were sold at \#70,000 to \#100,000, then the implications of fetal wastages in September is equals to 77 multiply by \#70,000 to \#100,000 which gives $\# 5,390,000$ to $\# 7,700,000$. In October 85 fetuses were wasted, the implications of fetal wastages 
in October is equals to 85 multiply by $\# 70,000$ to \#100,000 which gives $\# 5,950,000$ to $\# 8,500,000$.

Generally, the summing of October and November wastages gives us the total economic wastages of \#11,340,000 to \#16,200,000. This finding further confirm the findings of Adeyemi et al., (2016), who reported that an estimated sum of 600,000 naira which is equivalent to 3,530 USD was lost in sheep. A total sum of 11 million to 16 million naira was lost within the two months this study lasted. This is a huge economic loss to the livestock sector of the economy. Efforts should be made to reduce the occurrence of fetal wastage by effective ante-mortem meat inspection.If this lost is calculated over 1 year and multiplied by the 36 state capitals in the country. This therefore is a huge loss of animal protein and national revenue (lower GDP). This trend poses a threat to efforts to meet the dietary protein requirements of Nigeria with over 150 million people.

\section{CONCLUSION}

The results of these findings revealed that the prevalence of fetuses wastage and the economic implications resulting from the slaughter of pregnant cows at Jalingo abattoir of Taraba State are enormous, and this seems to escalate as much as the demand and consumption of cows meat is increasing. Furthermore, the percentage of fetuses wastage was high, and most of the fetuses were recovered in the second and third trimesters. The reason for this slaughtering pregnant cows ranged from poverty to ceremonies and diseases. Policy efforts must concentrate on instituting routine veterinary checks at control posts and abattoirs. Besides, it is noteworthy to ensure the establishment and enforcement of animal slaughter legislation which can prohibits the slaughtering of pregnant cows with the exception of the animals being culled.

\section{REFERENCES}

Abdulkadir,U.and Jiya, S. A. (2008): Survey of fetal wastage: A case study of Makurdiabattoir, Benue State, Pakistan Journal of Nutrition 7(3):450-452.

Adama, J.Y., Shiawoya, E.L. and Michael, N. (2011) Incidence of fetal wastages of cows slaughtered in Minna abattoir, Niger state, Nigeria. J. Appl. Biosci., 42: 2876- 2881.

Adedipe, N. O. (1996): Livestock estimate in Nigeria. In Timothy U. Obi (2007). Non - Parasitic Livestock Diseases in Nigeria; An overview. Trop. Vet 15,85-95.

Adeyemi, A.B., Adamu, M., Dawuda, P.M. and Oyedipe, E.O. (2016) The economic implications of fetal wastage in cattle, sheep and goats in Makurdi abattoir, Benue state, Nigeria. Niger. Vet. J., 37(4): 198-205.

Akpabio, U. and Babalola, A.S. (2014) Incidence of fetal wastage and its economic implications in cattle slaughtered at Abak slaughterhouse Abak, Akwa-Ibom state. J. Reprod. Infertil., 5(3): 65-68. 
Vol. 06, No. 01; 2021

ISSN: $2456-8643$

Atawalna, J., Emikpe, B.O., Shaibu, E., Mensah, A., Eyarefe, O.D. and Folitse, R.D. (2013) Incidence of fetal wastage in cattle slaughtered at the Kumasi abattoir, Kumasi, Ghana. GlobVet., 11(4): 399-402.

Bello, M. B.,Garba, H. S. and Sonfada, M. L. (2008): Fetal wastage in camels slaughtered at Sokoto municipal abattoir. Sokoto Journal of Veterinary Science: Volume 7(1).

Bisimwa, N.P., Lugano, R.M., Bwihangane, B.A., Wasso, S.D., Kinimi, E., Banswe, G. an BOECKM, BOECKM, E., BREMAND, O. DUMUS, R., ITUHU, J.E. and COMPARE, J.L. (1974): Study of the actual situation of livestock breeding in the countries of Sahel and preventive measures to be considered. In: Co-operation on prevention, reduction and eliminatio B.O

FAO (Food and Agriculture Organization of the United Nations). (2006) State of World Food Insecurity, FAO, Rome, Italy. p67.

Garba, S. and Hassan, A.A. (2002) Fetal wastages through slaughter of pregnant cattle at Sokoto abattoir.Trop. Vet., 4: 5-8.

Gillespie, J.R. (2003) Merder Livestock and Poultry Production. 7th ed. Bailliere. Tindal London, U.Kp753-754.

Ndi, C., Tambi, N.E. and Agharih, N.W. (1993) Reducing Calf Wastage from Slaughtering of Pregnant Cows in Cameroon. Available from: http://www.fao. org/documents/ art_dett.asp?lang=en\&art_id=54949. Last accessed on 11-11-2018.

IKEME, A.I. (1996): Meat science andtechnology. A comprehensiveapproach. Onitsha, Nigeria: AfricanFeb Publishers, 216pp.

Mshelia, G.D., Maina, V.A. and Aminu, M.D. (2015) Foetometrics and economic impactanalysis of reproductive wastages in ruminant species slaughtered in North-Eastern Nigeria. J. Anim. Prod. Adv., 5(4): 645-653.

Muhammed, B.F., Haruna, A.M. and Bichi, J.M. (2008). Foetal wastage in Northern Nigeria. The case of Gombe Abattoir. Proceedings of the 13th Annual Conference of the Animal Science Association of Nigeria. September 15 - 19, 2008. Ahmadu Bello University, Zaria pp 124 -127.

Oduguwa,(2013).Fetalslosses from slaughtering pregnant cows at Lafenwa abattoir,south west.PP.10-25n of losses and waste in livestock sector of West Africa and Cameroon. Quagadogu, Burkina

Okorie-Kanu, O.J., Ezenduka, E.V., Okorie-kanu, C.O., Anyaoha, C.O., Attah, C.A., Ejiofor, T.E. and Onwumere- Idolor, S.O. (2018) Slaughter of pregnant goats for meat at Nsukka slaughterhouse and its economic implications: A public health concern. Vet. World.

Nwakpu, P.E and Osakwe, I.I. (2007). Trends in volume and Magnitude of foetal Waste of slaughter Animals in Ebonyi State of Nigeria. Research J. of Anim. Sci. 1(1): 30 -Sanusi, M., Abubakar, M and Luka, B. (2006). Incidence of foetal wastage in ruminant animals slaughtered 
Vol. 06, No. 01; 2021

ISSN: $2456-8643$

at Bauchi and Jos abattoirs. Proceedings of the 31st Annual National Conference of the Society for Animal Production, Kano. Pp.102-106.

Swai, E.S., Ayubu, H. and Mhina, B.S. (2017) Incidence of fetal wastage in sheep and goats slaughtered at Tanga city abattoir, Tanga, Tanzania. Livest.Res Rural Dev., 27(10). Available from: http://www.lrrd.org/lrrd27/10/swai27213. html. Last accessed on 02-11-2018.

Wosu, L.O. (1988). Calf wastage through slaughtering of pregnant cows in Enugu Abattoir (Nigeria). J. of Anim. Hus. and Vet. Med. 41 